DOI: $10.1515 /$ pts-2016-0018

\title{
WAVE ENERGY POTENTIAL IN THE LATVIAN EEZ
}

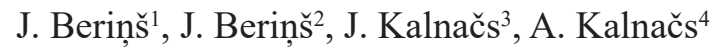 \\ ${ }^{1}$ Faculty of Power and Electrical Engineering, Riga Technical University, \\ 1 Kalku Str., Riga, LV - 1658, LATVIA \\ ${ }^{2}$ Faculty of Computer Science and Information Technology, Riga Technical \\ University, 1 Kalku Str., Riga, LV - 1658, LATVIA \\ ${ }^{3}$ Institute of Physical Energetic, \\ 21 Aizkraukles Str., LV - 1006, Riga, LATVIA \\ ${ }^{4}$ LLC Environment, Bioenergetics and Biotechnology Competence Centre, \\ 21 Aizkraukles Str., LV - 1006, Riga, LATVIA
}

\begin{abstract}
The present article deals with one of the alternative forms of energy sea wave energy potential in the Latvian Exclusice Economic Zone (EEZ). Results have been achieved using a new method - VEVPP. Calculations have been performed using the data on wave parameters over the past five years (2010-2014). We have also considered wave energy potential in the Gulf of Riga. The conclusions have been drawn on the recommended methodology for the sea wave potential and power calculations for wave-power plant predesign stage.
\end{abstract}

Keywords: Latvian EEZ, renewable energy, sea wave potential, wave energy, wave energy distribution of time wave energy directional distribution.

\section{INTRODUCTION}

Up till now, sea waves are an untapped source of energy in Latvia. Wave energy is a renewable resource, which is increasingly used worldwide. Its volume can be estimated between 80,000TWh and 8,000TWh [1]. Several authors believe that wave energy could also become one of the most promising energy sources for electricity generation in our country [2], [3]. For wave energy to be captured and transformed, wave power stations are required. Technical solutions that determine whether they will be profitable are dependent on specific local conditions. To find them, an objective assessment of wave energy potential is required. The following factors are essential for this assessment:

1. The potential amount of energy;

2. Wave expansion in different directions;

3. Wave energy variability over time. 
To meet this challenge, the following is required:

1. Wave output parameter data of the maritime area of interest;

2. An optimal wave energy calculation method;

3. The calculation of results and their analysis and evaluation.

\section{THE MAIN CHARACTERISTICS OF SEA WAVES}

Sea waves along the Latvian coast of the Baltic are irregular. Wave height, period and wave propagation direction are random variables. Choosing sufficiently short intervals and a small enough surface on the sea, for example, $1 \mathrm{~m}$ x $1 \mathrm{~m}$ we can assume that this parameter (wave height, period and direction of spread) change can be described by means of probability theory as a stationary random process. In this case, calculating the energy potential is the most appropriate wave frequency ${ }^{1}$ power density spectrum $S(f)$, [4]. The spectrum of our case is characterized by the following parameters:

$H_{s}$ - characteristic wave height $=H_{m 0}(\mathrm{~m})$;

$T_{z}$ - average wave period (zero crossing) $=T_{e}(\mathrm{~s})^{2}$; trum;

$T_{p}$ - the wave period, which corresponds to the maximum energy of the spec-

$\theta_{v i d}$ - average angle of wave propagation direction.

Characteristic wave height - swh (significant wave height) wave parameters in meters, which characterize irregular wave water surface fluctuations and determine the energy density spectrum. $s w h$ is used in a variety of wave energy and power calculations in deep, medium and shallow water. Elsewhere this parameter is represented by the $H_{s}$. Historically, the characteristic wave height is the average wave height of $1 / 3$ of the maximum wave period examined (see Fig. 1) [5].

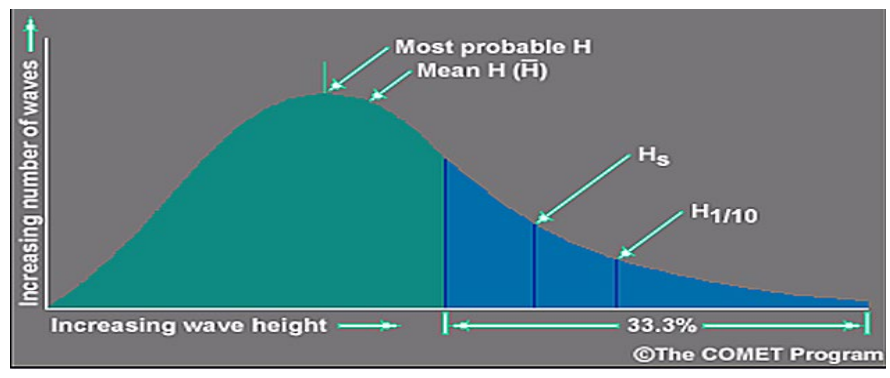

Fig. 1. Definition of characteristic wave height illustration [5].

It is believed that the characteristic wave height $H_{s}$ is shown more precisely by $H_{m 0}$ than by $H_{1 / 3}[6$, p. II - $1-88(5)] . H_{m 0}$ is obtained by processing the power density spectrum $S(f)$ according to the expression:

$$
m_{0}=\int_{0}^{\infty} S(f) d f,
$$

where: $m_{o t}-$ the 0 -th spectral moment, random variable or variate 0 -th moment is constant, the determined auxiliary value uses different variant values, including $H_{m 0}$ the calculation being: 


$$
H_{m 0}=4 \sqrt{m_{0}},
$$

Average wave period $\boldsymbol{T}_{z}$ - wave parameters in seconds characterized by irregular wave water surface fluctuations and by the energy density spectrum. Since it is less than or equal to the energy wave period $T_{e}$, wave energy and power evaluation are used in calculations.

$T_{e}$ - wave power density spectrum average energy periods, the energy density range of -1 and 0 consecutive moments linking the relationship $T_{e}=m_{-I} / m_{0}$.

$m_{k,}$ or $\mathrm{k}$ - the spectral moments - is defined as:

$$
m_{k}=\int_{f-0}^{\infty} f^{k} S(f) d f
$$

K-th order spectral moment is a specific constant determining the shape characteristics of the set of points applied in the mechanics and statistics (probability distributions and spectra $)\left(m_{1}\right.$ mechanics - the sum of mass $=$ center of mass, $m_{2}$ rotational inertia), where $\mathrm{k}$ can be: $-4-3, \ldots, 0,1,2,3,4$

Main wave direction mwd (mean wave direction) - wave parameter in degrees, which is characterized by irregular wave water surface fluctuations and energy directional spectrum. It is used in areas with real or notional receiver lines for wave energy potential evaluation. This is the direction which the waves come from in any prevailing wave period (DPD) [7]. Output data $m w d$ is assigned as the azimuth.

\section{DESCRIPTION OF THE FIRST DATA USED IN CALCULATIONS}

The following criteria were used to select Control Points:

1. Sea area " $A$ " (see Fig. 2) - the eastern Baltic Latvian exclusive economic area (EEA) waters are $216 \mathrm{~km}$ long and $95 \mathrm{~km}$ wide;

2. South-western and western winds in this area are prevailing [8]; [13], and therefore the direction of the waves is an important source of wave energy;

3. South-western and western winds are also prevailing in the eastern part of the Gulf of Riga - so it was decided to expand the project's initial task of examining the wave potential not only in maritime area " $A$ ", but also in maritime area " $B$ " (see Fig. 3);

4. Area " $B$ " - the eastern part of the Gulf of Riga could be a potential wave energy source;

5. We chose six control points in the Baltic Sea area " $A$ " by the Latvian coast, and one point of the Gulf of Riga opposite Salacgriva - area " $B$ ";

6. The selected Control Point coordinates and their existing depths are shown in Table 1, and the visual location on the map in Fig. 3;

7. Most of the waves will not be longer than $70 \mathrm{~m}$. This means that the minimum depth is $17.5 \mathrm{~m}$, as up to $95 \%$ of the wave energy is dispersed in the layer between the water surface and depth equal to a quarter of the wave length [9], [10]. 
Coordinates and Depth of Chosen Control Points

\begin{tabular}{|l|c|c|}
\hline Control point No. & Coordinates & Debth, $\mathrm{m}$ \\
\hline 1 & $56.060,20.898$ & 24 \\
\hline 2 & $56.503,20.810$ & 18 \\
\hline 3 & $57.048,21.234$ & 24 \\
\hline 4 & $57.421,21.381$ & 56 \\
\hline 5 & $57.645,21.601$ & 21 \\
\hline 6 & $57.746,24.184$ & 31 \\
\hline 7 & $56.400,20.810$ & 24 \\
\hline
\end{tabular}

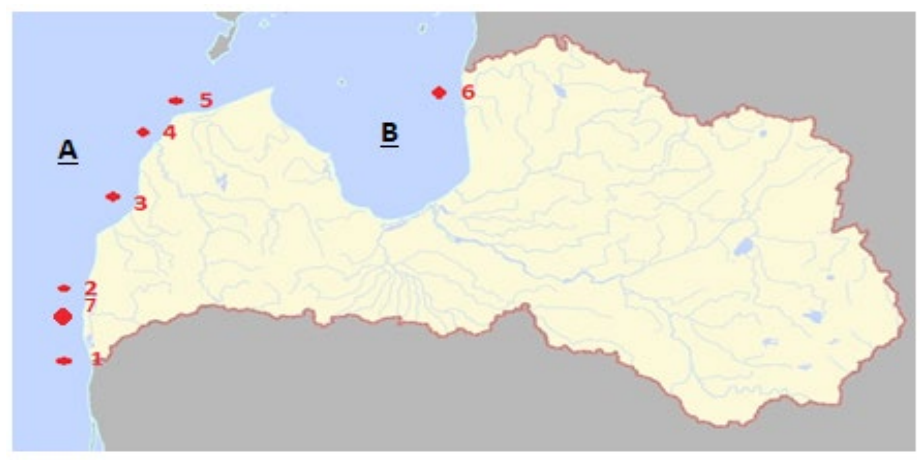

Fig. 2. Illustration of distribution of Control Points.

It is possible to indirectly determine statistical data of wave parameters in areas such as the Baltic Sea EEZ Latvian west coast, where measurements have not been made in sufficient quantity and quality to allow for the assessment of the energy potential of the region. It is based on data on wind direction and strength, and the corresponding processing algorithm adjustment points where the comparison of results with direct measurements are possible [14]. We use data based on the Danish Meteorological Institute (DMI) wave model adjusted to the program SWAN. They are received by using a special modelling program, processing satellite data on wind direction and speed as well as satellite data on wave height. Since we do not have local technical resources, which provide the data for the spectrum parameter adjustment, we will use wave energy density spectrum characteristic parameters [10]. They are $H_{s}(s w h), T_{z}$ and MWD data collected over the previous five years (2010-2014).

For the wave energy potential calculation we will use the raw data from seven Control Points (see Fig. 2). The basic data of the calculation are the sea wave energy density spectrum characteristic parameters of the seven Control Points at given depths for every hour of 24 hours a day, every day of the month and every month 12 months of the year, every year, for five consecutive years (2010-2014). Assuming that the meteorological and hydrological conditions in our chosen area are sufficiently homogeneous, the calculated results can be related to the adjoining sea $+/-5 \mathrm{~km}$. DMI data are in increments of about $10 \mathrm{~km}$ [6].

From the wave start / input data, it is evident that the $m w d$ values are reviewed every $1^{\circ}$ in the $360^{\circ}$ spectrum. Moreover, this parameter indicates only the dominant, but not all wave directions each hour. 


\section{METHOD OF CALCULATION CHOSEN}

The simplest method is to calculate the specific wave power and wave energy at separate points in the area [2], [3].

The following method: a defined wave receiver line is drawn in the sea (a straight line segment or several segments at shallow angles) [10], and the entire energy flow calculated through a vertical plane passing through the line receivers in one direction. Each wave direction energy flow and the direction of wave energy during the distance unit would fall $\cos \theta$ times, where $\theta-$ the angle at which the wave front forms with the defined receiver line.

The whole border of the area serves as the vertical surface receiver across the whole depth of energy release. Cumulative flow of energy per year (TWh) is determined by the average wave power $P_{v i d}(\mathrm{~kW} / \mathrm{m})$ or wave of energy flow through the surface - EPRI (Electric Power Research Institute) methodology [16].

These methods have some obvious shortcomings:

1. Assessment of the potential energy depends on the relative receiver line placement, because it determines the angle $\theta$, on which it depends, as to how much the energy potential assessment decreases;

2. It is an energy assessment of the potential of the notional receiver lines and so there is no energy assessment of the potential of the area, as it does not allow for the possibility that the receivers' mutual positions could be changed, which would be a normal strategy in the case of an increase in perceptible energy, when receivers would automatically reorientate or be reorientated to working position;

3. Even assuming the direction of wave energy distribution spectrum can be described as a narrowband spectrum, angle $m w d$ does not describe the amount of all incoming energy, but only part of the amount;

4. If you use the border area method, problems in evaluating wave energy arise due to wind changes in this area.

In order to mitigate these shortcomings in the assessment of wave energy, we offer the wave energy direction baseline projection (VEVPP) method.

1. On the energy spectrum by integrating the frequency range $[0 ; \infty]$, we calculate the average wave energy density $J_{v i d}$ of time interval of $1 \mathrm{~m}^{2}$ field:

$$
J_{v i d}=\rho g \int_{0}^{\infty} S(f) d f=\rho g m_{0}=\frac{\rho g\left(H m_{0}\right)^{2}}{16}=\frac{\rho g(H s)^{2}}{16}
$$

where: $\rho$ - sea water density $\mathrm{s}, \mathrm{kg} / \mathrm{m}^{3} ; g$ - gravity acceleration, $\mathrm{m} / \mathrm{s}^{2} ; f$ - wave frequency, $H z ; S(f)$ - wave energy spectrum function; $m_{0}-0$ th spectral moment; deep water:

$H_{m 0}=H_{s}$ - characteristic wave height, $\mathrm{m}$; The wave phase velocity $-c_{g}$ in

$$
c_{g}=c_{f},
$$

where: $c_{f}$ - wave phase velocity; $T$ - average wave period $T_{z}$ (zero crossing); as mentioned above, it is replaced by $T_{e}(\mathrm{~s})$. 
The wave average power in a $1 \mathrm{~m}$ wide wavefront or wave energy flow through the vertical plane perpendicular to the wave direction of movement is expressed as:

$$
P_{\text {vid }}=J_{\text {vid }}^{*} \cdot c_{g}
$$

Consequently, irregular wave energy, crossing the plane perpendicular to the direction of movement of the wave, in a time interval on a $1 \mathrm{~m}$ wide wavefront is expressed as:

$$
E=P_{v i d}^{*}
$$

According to (7), specific calculations of wave energy are performed in each of the 6 selected control points at $n$ (time) intervals.

2. The Baltic Sea area " $A$ " is perpendicular to 8 traditional wind and wave axes ( $P V x x$ where: $x x=(N, N E, E, S E, S, S W, W$ and $N W)$. We set baselines perpendicular to the direction. Thus, we have 4 lines which intersect each other at one point and cross the border area from 4-way baseline segments $B N y y$ where $y y=(N-S, E-W$, $N E-S W, S E-N W$ ) (Fig. 3).

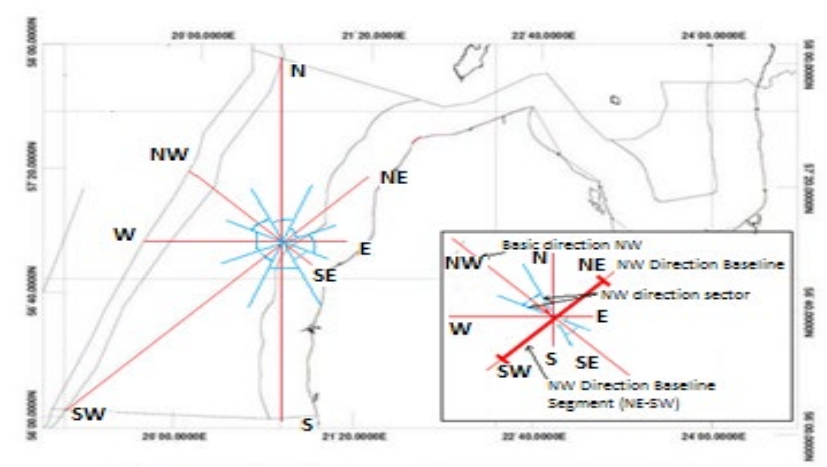

Fig. 3. Basic wave direction sea area " $A$ ” base line segments [11].

3. On line segment BNyy we construct and fix perpendicular control point $\mathrm{Km}$, where $\mathrm{m}=(1,2,3,4,5,7)$ projections $K m_{\mathrm{N}-\mathrm{S}}, K m_{\mathrm{E}-\mathrm{W}}, K m_{\mathrm{NE}-\mathrm{SW}}, K m_{\mathrm{SE}-\mathrm{NW}}$.

4. We introduce a selective $m w d$ directional filter at control points to assess specific wave energy directional distribution.

$$
\begin{aligned}
& I F\left(m w d_{i}, P V x x_{\text {min }}, P V x x_{\text {max }}\right)=1, \text { if } P V x x_{\text {min }}<m w d_{i} \leq P V x x_{\max } \\
& I F\left(m w d_{i}, P V x x_{\text {min }}, P V x x_{\text {max }}\right)=0, \text { if } m w d_{i}>P V x x_{\text {max }} \text { or } \\
& P V x x_{\text {min }} \geq m w d_{i} .
\end{aligned}
$$

5. Thus, the summation of wave energy direction (7) during time interval $\Delta t$ in each of the control points by sector accounts for mutually non-duplicative direction of wave energy. 


$$
\dot{E}_{n}(K m P V x x)=\Delta t \cdot \frac{\rho g^{2}}{64 \pi} \sum_{i=1}^{n} I F\left(m w d_{i}, P V x x_{\min }, P V x x_{\max }\right)\left(T e i(H s i)^{2}\right)
$$

where: $P V x x$ - one of the axes $x x=(N, N E, E, S E, S, S W, W, N W) ; P V x x_{\text {min }}$ - the key sector $P V x x$ minimum limit; $P V x x_{\max }$ - the key sector PVxx ceiling; $H_{s i .}-$ characteristic wave height of $\mathrm{i}$-th time interval $\Delta t ; T_{e \mathrm{i}}$ - i-th mean energy period of wave energy density spectrum; $P V x x$ sector size is equal to $P V x x_{\max }-P V x x_{\min }=45^{\circ}$, (see blue lines in Fig. 3).

In addition, the following summation of the direction of various wave energy by sectors reduces the errors that arise from the assumption that all the energy interval of time $\Delta t$ point is associated with only one wave direction $M W D$.

As a result, we obtain the wave's specific energy assessment in $\mathrm{xx}$ (Ws), $\mathrm{n}$ intervals $\Delta t$ ( $\Delta t=1$ hour, or 3600's) in eight basic sectors at each Control Point, which are attributed to the direction of the base cut-off point projection $\mathrm{Km} \mathrm{xx}$.

If the resulting energy is measured in $\mathrm{kWh}$, then inserting $\Delta t=3600 / 1000$, $\rho=1003 \mathrm{kgm}^{3}, \mathrm{~g}=9.81 \mathrm{~m} / \mathrm{s}^{2}$ and $\pi=3.14 \mathrm{rad}$ cumulative energy can be expressed as:

$$
\dot{E}_{n, m, x x, y y} 480,32 / 10^{3} \cdot \sum_{i=1}^{n} I F\left(m w d_{i,} P V x x_{\min ,} P V x x_{\max }\right) \cdot\left(T i(H s i)^{2}\right)
$$

This equation characterizes control point Km wave energy potential of the key $P V x x$ projection point intervals of any specific baselines $P N y y$, where the number $\mathrm{n}$ may be the time interval of one month $=672 \mathrm{~h}$, if the month has 28 days, or one month $=744 \mathrm{H}$ if the month has 31 days.

One year Energy potential of Control Points $K_{m}$-th for a $1 \mathrm{~m}$ wide wave front $E_{g}$ is calculated as:

$$
\dot{E}_{g, m, x x, y y}=\sum_{n=1}^{12}(E n, m, x x, y y)
$$

6. Thus, knowing basic sectors $P V_{x x}$ specific energy values $\dot{E} n\left(K m_{x x}\right)$, control projection points $K m_{x x}$, to get direction $P V_{x x}$ specific energy curve, which corresponds to the base line segment, we execute the function approximation. Comparing different approximation method results, including fourth and fifth grade interpolation curves, we chose the horde method, which simplified the following specific energy integration process, without sacrificing the accuracy of the results.

This method consists of replacing points of some specific energy wave function with a straight length cutline of the polygon and the amounts in each direction of the basic line projection segment $\Delta L\left(K 1_{x x}, K 5_{x x}\right)$.

7. Directional control baseline projection of corresponding energy can be calculated by integrating the distance within the projection of the specific energy function. Thus, the integration process reduces the expression to the trapezoidal method [14] used:

$$
\begin{aligned}
& \operatorname{Exxyy}(K 1, K 5)=\sum_{m=1}^{m+1=7} E(\Delta L(m, m+1) x x)= \\
& =\sum_{m=1}^{m+1=5} \frac{\dot{E} n(K m)+\dot{E} n(K m+1)}{2} \cdot \Delta L(m, m+1) x x
\end{aligned}
$$


where: $m$ - control point projection $K m_{x x}$ sequence number $(1,2,3,4,5,7)$; $m+1-$ control point projection $K m+1_{x x}$ sequence number; $\Delta L(m, m+1)$ - the distance between the projection points to the direction of the base, taking into account the baseline azimuth and control coordinates (see Table 1).

8. Knowing the wave energy potential of the control area with the checkpoints $K 1 ; K 2 ; K 3 ; K 4 ; K 5$ and $K 7$, which mark the control projection of the direction of the baselines (see Fig. 4), and knowing that the control area also represents a significant share of the test area " $A$ " as well as taking into account the assumption that the wave energy distribution in time and space is uniformly distributed, we are able to evaluate each of the key $P V x x$ amounts of energy, increasing in proportion to the direction of the baseline segment $P N y y$ and control the projection pieces which total $L(K 1, K 5)$ yy ratio.

9. The sum of 8 wave energy potential projections is the total wave energy potential per month / year.

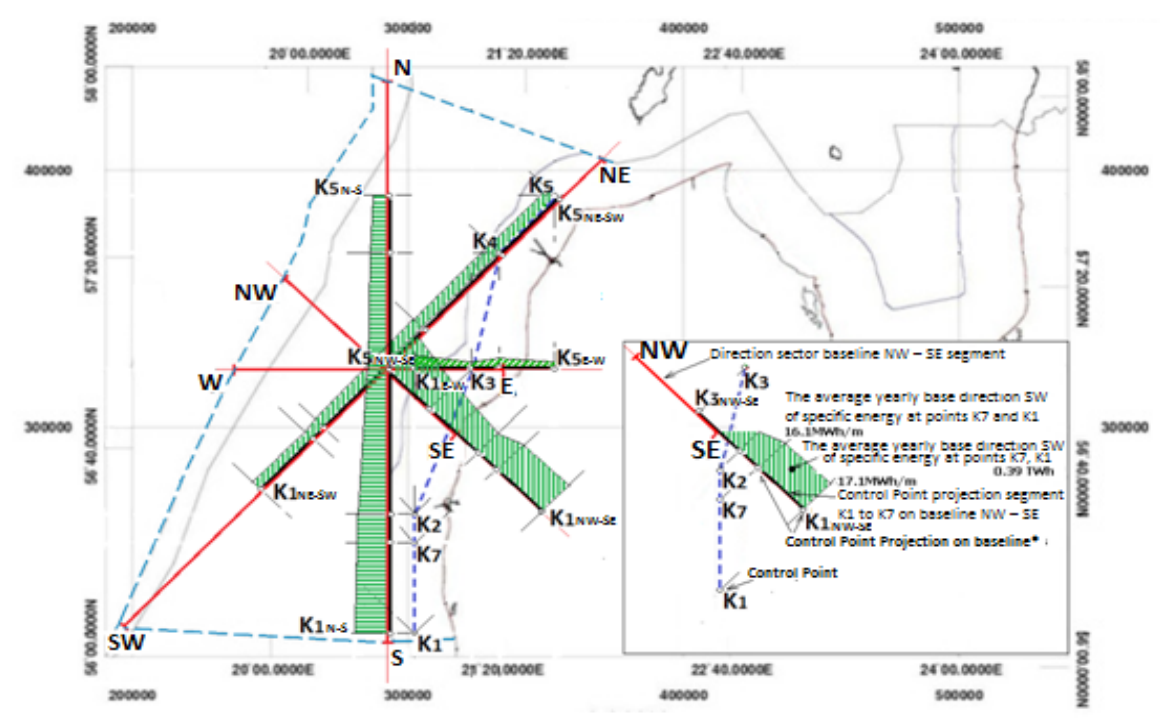

Fig. 4. The average annual wave energy direction projection of Baltic Sea Area " $A$ ”.

10. Since the VEVPP method includes calculations related to the outcomes of several control point placements in the plane, to evaluate the result we used a simpler method of wave energy assessment, defined in one of the selected control points $(K 7$, the specific energy average volume over one year is close to the average of the test control group) specific energy in a special way related to the whole area. Their many time intervals - $\Delta t$ component $\dot{E}_{n}\left(n, \theta_{n}\right)$ are graded and summated using $m w d$ through eight basic $P V x x(x x=N, N E, E, S E, S, S W, W, N W) 45^{\circ}$ sectors, gaining 8 average specific energy $\dot{E}_{g 7,} x x$ components. Each component is multiplied by one of the corresponding four-base line piece lengths $P N_{y y}$, thus obtaining an approximate area of energy height-directional distribution assessment $E g 7(P V x x, P N y y)$ ( $y y=N-S, N E-$ $S W, E-W, N W-S E)$. Summarizing, we obtain comparative average energy potential assessment over one year in Latvia's EEZ. 


\section{RESULTS OF LATVIA'S EEZ WAVE POTENTIAL CALCULATIONS}

1. When using two methods $-Z_{0}$ and VEVPP, results were obtained for wave energy potential of Latvia's EEZ in the Baltic Sea area " $A$ ” (see Fig. 2) in accordance with 6.46 TWh / year and 6.51 TWh / year.

2. Using the wave energy direction distribution calculation method of receiver conventional directional line segment, the following results were obtained:

a) Average annual wave energy directional distribution in the reporting period;

b) The average amount of monthly breakdown of wave energy direction for each year during the reporting period;

c) The directional distribution of annual average wave energy volume;

d) The directional distribution of annual average wave specific energy in the reporting period (examples of control points $K 5, K 6$ and $K 7$, Fig. 8).

3 . The calculations were made in 7 control points during the period of 2010 2014:

a) Hourly interval wave specific energy;

b) Monthly wave specific energy (examples of $K 5, K 6$ and $K 7$ - Fig. 9);

c) The annual average specific wave energy (see Fig. 5).

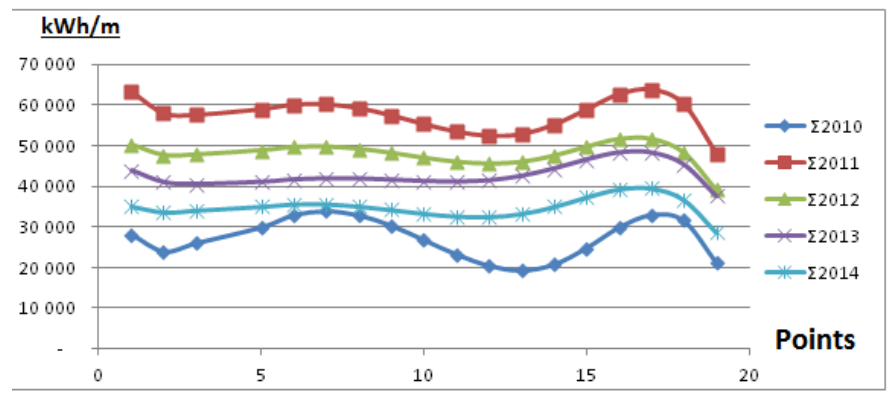

Fig. 5. Baltic Sea wave energy specific potential (2010-2014) points $N 1-N 19(\mathrm{kWh} / \mathrm{m})$.

By summarizing the specific potential of the data on a monthly basis as well as by interpolating these results, the evaluation of the specific energy potential points N1-N19 was obtained (Fig. 6).

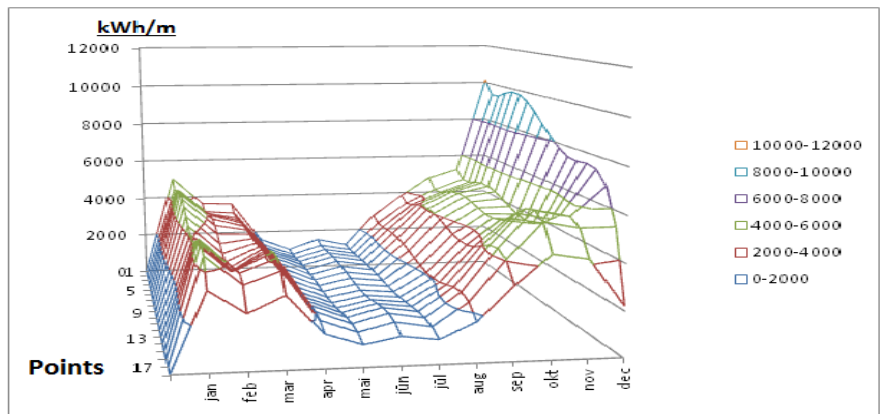

Fig. 6. Monthly average (2010-2014) of specific energy potential points $N 1-N 19(\mathrm{kWh} / \mathrm{m})$. 


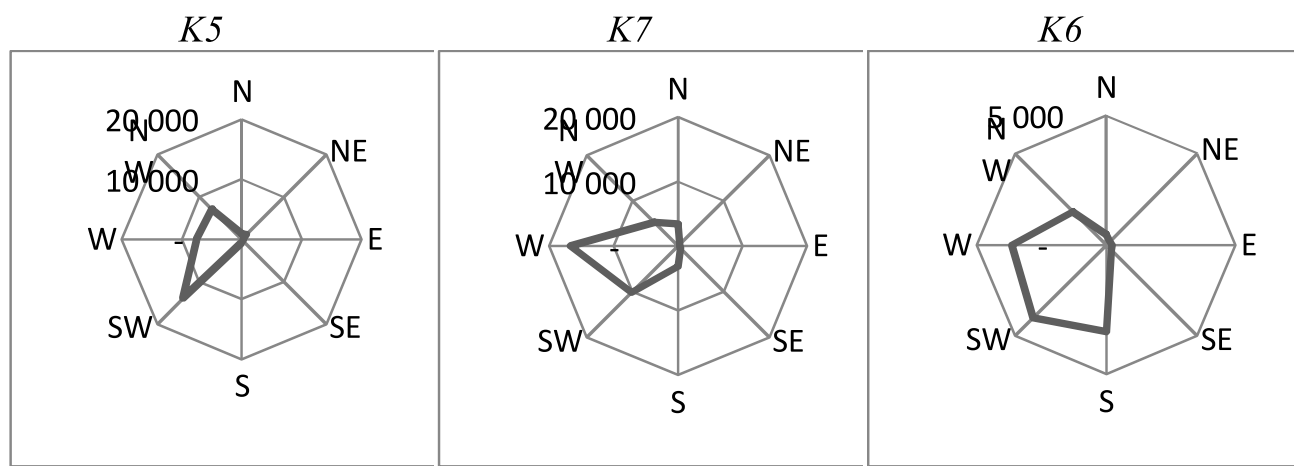

Fig. 7. The average of the specific energy direction distribution of Control Points K5, K6 and $K 7$ (in kWh/ m).

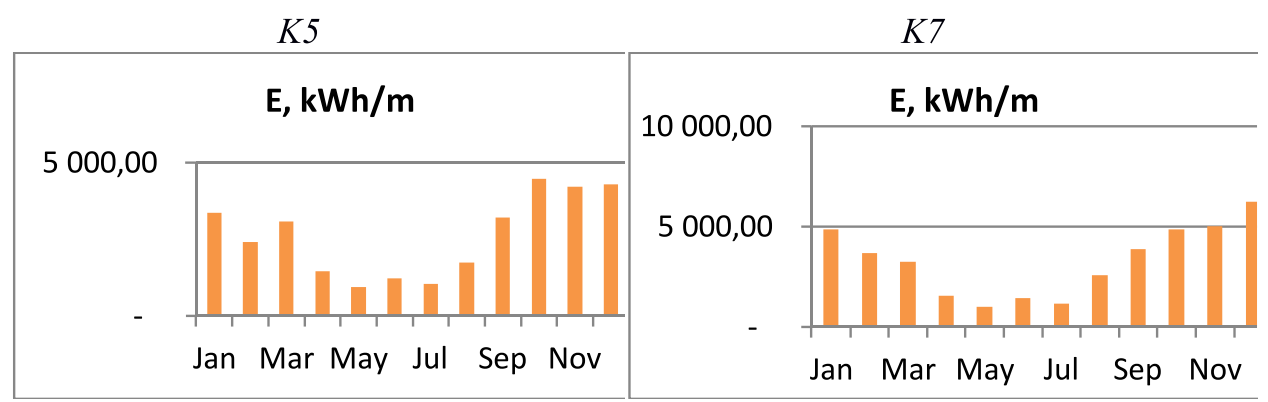

K6

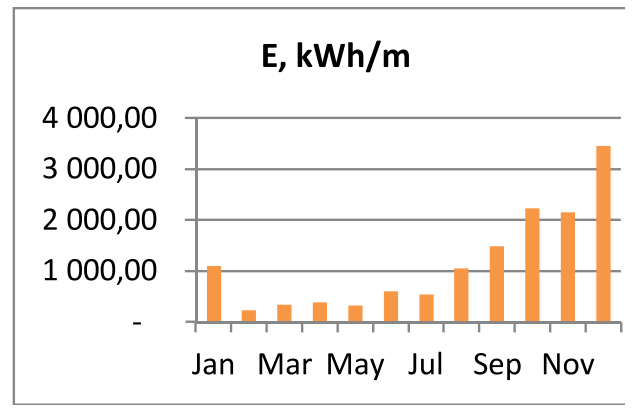

Fig. 8. Monthly breakdown of specific energy $(\mathrm{kWh} / \mathrm{m})$ at Control Points $K 5, K 6$ and $K 7$.

\section{CONCLUSIONS}

1. The amount of wave energy in $1 \mathrm{~m}$ wide waves in the Gulf of Riga is about 3 times less than the corresponding figure for the Baltic Sea Latvian EEZ. It is considered that the main causes are wave formation distances and ice formation conditions.

2. At least $90 \%$ of the wave energy in the Baltic Sea Latvian part of the EEZ comes from the South West - West and North West axes.

3. The complicated energy direction distribution points to the fact that potential SWPS placement will depend on the receiver's functioning angle range. 
4. Calculating the Baltic Sea Region " $A$ " wave energy potential using VEVPP method the result is $6.51 \mathrm{TWh} /$ year. Using comparative evaluation obtained by the method based on different control point principles of location, it is on average $6.46 \mathrm{TWh} /$ year $(-0.77 \%)$. The results are close which means that the new method of wave energy distribution assessment is plausible. Wave energy direction projection method compared to traditional methods more evenly and fully accounts for the different directions of energy in the area.

\section{ACKNOWLEDGEMENTS}

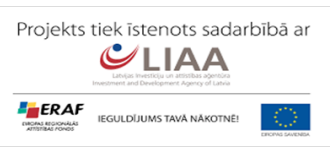

The research has been supported within Project No. L-KC/2.1.2.1/10/006, according to contract No. L-KC-110005 between Ltd "Vides, Bioenergétikas un Biotehnologijas Kompetences Centrs" and Latvian Investment and Developement Agency (11th April 2011).

\section{REFERENCES}

1. Holmberg, H., Anderson, M., Bolund, B., and Stananger, K. (2011). Wave Power, Surveillance Study of the Development, Elforsk rapport 11: 02.

2. Beriņš, J., and Beriņš, J. (2015). Viḷnu enerǵêtikas faktoru un attīstības perspektīvu analīze Latvija. E\&P 6.

3. Avotiņš, A., Greivulis, J. and Kalniņš, L. (2008). Baltijas jūras potenciāls viḷna energíjas pārveidošanai. Enerğêtika un Elektrotehnika 23, ISSN 1407-7345.

4. Prat, M.C. (2008). Owerwiew of Ocean Wave Statistics. Available at https://upcommons. upc.edu/bitstream/handle/2099.1/6034/06.pdf?sequence=7

5. Comet Met Ed. Available at https://www.meted.ucar.edu/sign_in.php?go_back_ to $=$ https $\% 3 \mathrm{~A} \% 2 \mathrm{~F} \% 2 \mathrm{Fwww} . \mathrm{meted} . u \mathrm{car} . \mathrm{edu} \% 2 \mathrm{Fmarine} \% 2 \mathrm{Fmod} 1$ _w _ char\%2Fnavmenu.php\%3Ftab\%3D1\%26page\%3D5.2.1\%26type\%3Dtext\#\#

6. DMI Ocean and Ice services. DMI WAM model. Available at http://ocean.dmi.dk/models/wam.uk.php

7. National Data Buoy Center. Available at http://www.ndbc.noaa.gov/measdes.shtml

8. Bojārs, E. (2009). Aizsargājamās jūras teritorijas N̦ida-Pērkone. Dabas aizsardzības plāns. Available at http://www.daba.gov.lv/upload/File/DAPi_apstiprin/AJT_NidaPerkone09.pdf

9. Guiberteau, K.L., Liu, Y., Lee J., and Kozman, T.A. (2012). Investigation of Developing Wave Energy Technology in the Gulf of Mexico. Available at http://www.aeecenter.org/ files/newsletters/CWEEL/WaveEnergy.pdf

10. Soomere, T. and Eelsalu, M. (2016). On the wave energy potential along the Eastern Baltic Sea coast. E\&P 6.

11. JONSWAP. Available at http://www.codecogs.com/library/engineering/fluid_mechanics/waves/spectra/jonswap.php

12. MK noteikumi. Nr.779 (17.08.2010.). Noteikumi par bāzes līniju punktu koordinātēm.

13. Soomere, T., and Keevallik, S. (2001). Anistropy of moderate and strong winds in the Baltic Proper. Proc. Estonian Acad. Sci. Eng. 7(1), 35-49. 
14. Zviedris, A. (2004). Datorrealizācijas matemātiskās metodes. Lekciju konspekts. RTU 78.

15. World Meteorological Organization. (1998). Guide of Wave Analysis and Forecasting. 702. Available at https://www.wmo.int/pages/prog/amp/mmop/documents/WMO\%20 No\%20702/WMO702.pdf

16. Jakabson, P. (2011). Mapping and Assessment of the United States Ocean Wave Energy Electric Power Research Institute. Technical report. Available at http://www1.eere.energy.gov/water//pdfs/mappingandassessment.pdf.

\title{
VIḶN̦U ENERG̣IJAS POTENCIĀLS LATVIJAS EEZ
}

\author{
J. Beriň̌̌, J. Beriňš, J. Kalnačs, A. Kalnačs
}

Kopsavi $1 \mathrm{kums}$

Raksts ir par vienu no atjaunojamās enerğijas veidiem, kurš nerada būtisku piesārṇojumu - jūras viḷnu enerğiju. Konkrētāk, par šīs enerğijas potenciālu Latvijas EEZ (ekskluzīvā ekonomikas zonā). Tā noskaidrošanai lietota jauna metode. Aprēķinu veikšanai ir lietoti piecu gadu (2010. - 2014.) dati - viḷnu augstumi, periodi un virzieni. Apskatīts arī viḷnu enerğijas potenciāla aprēḳins Rīgas Jūras līcī. Izdarīti secinājumi par ieteicamo metodiku viḷnu spēkstaciju pirms-projektēšanas potenciāla un jaudu aprēkiniem.

02.05.2016. 